\title{
Mitochondria and Nuclear changes in postimplanted mice embryos After treatment with Cisplatim antitumour drugs
}

\author{
Hassan M.El Ashmaoui \\ National Research center, Cell Biology Dept., Giza, Egypt
}

\begin{abstract}
To evaluate a possible relationship of maternal exposure to capsulation during postimplantation embryotoxicity, SWR pregnant female mice were injected intraperitoneally on day 4 of gestation with $7 \mathrm{mg} / \mathrm{kg}$ cisplatin or with saline $(0.4 \mathrm{ml})$ for the control group. Embryos were collected after $24 \mathrm{~h} 48 \mathrm{~h}, 72 \mathrm{~h}$, after injection. ultrastructural sections were used to investigate the mitochondria and the nuclear changes Both the mitochondria and the nuclei were damaged specially $48 \mathrm{~h}$ and $72 \mathrm{~h}$ after injection they may be related to cytotoxicity of the drug.
\end{abstract}

Key words: platinum antitumour drugs, Mitochondria, Nucleus, Mice embryos.

\section{Introduction}

Cisplatin has been approved for clinical use on limited basis in treating testicular and ovarian tumors (Rozencweig et al 1977) it is a highly cytotoxic drug first discovered by Rosenberg (1975)during his study on the effect of electric field on the cellular growth.

It has been reported to interact mainly with the nuclear compartment where it blocks DNA replication and separates the tow components of the nucleolus (Pinto and Lippard, 1985; Burhn et al 1991).

However, effective chemotherapy with cisplatin alone or in combination with other drugs on a wide variety of animal and human tumors is still not free of side effect effects such as kidney toxicity, gastrointestinal, nephro and neurotoxicity and also embryo toxicity, (Rosenberg, 1985; Mollman, 1990;Amand and Bashey, 1993).

We now believe that cisplatin coordinates with DNA and this coordination complex not only inhibits replication and transcription of DNA, but also leads to programmed cell death (called apoptosis).

The primary action of cisplatin is on DNA resulting in the inhibition of DNA synthesis. The cytoarchitecture of the nuclei and cytoplasmic organoids may be expected to be altered after treatment with cisplatin (Aggarwal and Sodhi 1973; Rosen et al, 1992)

This presentation, which is based on electron microscopy studies, is an attempts to elucidate the effect of cisplatin on normal embryo cells to explore some possible avenues that can be followed to combat its toxic side effects.

\section{Material and Methods}

Inbred normal SWR/J male and female mice, 8-10 weeks old and weighting 28-30 g, were used throughout this study. Animals were kept and bred in environmentally controlled room with a temperature of $22 \pm \mathrm{c}^{\circ}$ a relative humidity of $45 \pm 5 \%$ and light /dark cycle of 10/14h mouse food commercially available and water was offered ad libitum.

In each box 4-5 milliparous females were caged together with a single male. The females were examined each morning for the presence of vaginal plug; the day that plug was detected was considered as day 0 of gestation and the pregnant females were placed in separated cages.

A total of 30 pregnant females were used, and divided into 6 groups 5 females in each.

Group I, II, II, were treated with a single intraperitoneal injection of $7 \mathrm{mg} / \mathrm{kg}$ of Cisplatin in day 4 of gestation and with $0.4 \mathrm{ml}$ normal saline in group IA, IIA, IIIA, as control group for each group.

Female mice were killed by cervical dislocation after $24 \mathrm{~h}$ in groups I, IA, $48 \mathrm{~h}$ for groups II, IIA, and after $72 \mathrm{~h}$ for groups III, IIIA.

The abdominal cavity wall for each female was opened and both uterine horns 
were properly exposed to their full extent. The fetuses were removed and fixed for transmission electron microscopy.

All embryos were fixed in $3 \%(\mathrm{~V} / \mathrm{V})$ Glutraldhyde buffer. The specimens were dehydrated ingraded ethanol, transferred to propylene oxide and finally embedded in araldite (serva) embedding medium.

Ultrathin section were stained with methylen blue and azure A, whereas ultrathin sections were contrasted with uranylacetate and lead citrate before examination The sections were examined photographed by a JEOL 1200 EXII transmission electron microscope.)

\section{Result and Discussion}

Electron micrographs showed that cisplatin treatment produced elongated mitochondria with irregular cristae with permanent sings of disintegration in cells of embryo taken from female after $48 \mathrm{~h}$ group II (Fig 2 a,b,c)compared to control group IIA (Fig 6a).

In group III (72h) some abnormal mitochondria exhibit extensive vacuolation, disappearance of cristae and dilated mitochondrial membranes, also specific mitochondrial lesion and mitocondrial degeneration was observed in this group (Fig 3a,b) compared with control (Fig 7a) .

Damage of mitochondria was started in group in group IA(24h) (Fig1a) compared to control(Fig5a ). In this group the mitochondria appear to start the morphological changes .

The nuclei of a cell embryo from treated females (group IIA) shown condensed chromatin scattered in the form of distinct chromocenters (Fig 4a). A substantial increase in the number of perichromatin granules was noted .

Perichromatin granules with dense granular element in the nucleolus, a lot of lysosomes with vriable sizes could be observed with highly disintegrated cytoplasmic organoids specially RER. Vacuolated nucleus with marginal chromatin and irregular nucleolus was noted also in the group IIIA (Fig 4b) compared to control (Fig6b, 7b,).

Nuclear lesions when detected in treated groups showed highly compact and often segregated nucleoli as well as nuclear degenerative changes which were characterized by chromatin margination, loss of nuclear organelles, dissolution of nucleolar structure and the appearance of dense granular element throughout the nucleoplasm, (Fig4b) compared to normal structure in control (group. IIIA)(Fig7b). On the other hand there are no changes in the nucleus in-group I (24h) compared to control in groupIA. (Fig 1b, 5b).

In the present study there is a marked damage and many changes in mitochondria and nuclei these changes may be due to the toxic effect on glutathion was early event for oxidative stress on mitochondria because cisplatin induces depletion in glutathion and cause lipid perioxidation and increased of lipid peroxidation of mitochondrial, these depletion of glutation (gsh) was an early event and appeared to be determinant step in this oxidative stress to mitochondria (Zhang and Edward, 1994).

Also Zhang and Lindup (1994) showed that cisplatin added in vitro markedly depleted the protein -SH groups of mitochondria and inhibited $\mathrm{Ca}$ uptake by the mitochondria, and that it also collapsed the mitochondrial potential capacity .

The main finding of this ultrastructural study is that the mechanisms involved in the embryotoxic effects of these drug appears to be connected to an interference with the functions of the nucleic acid.

It has been reported that cisplatin creates and interstand DNA cross link (.Giavini et al 1990, harder, 1970).

Pinto and lippard, (1985) and Bellon et al (1991), mentioned that the interact of cisplatin mainly with the nuclear compartment where it blocks DNA replication and separates the two components of the nucleolus.

In conclusion, the present morphometric study has shown that treatment of pregnant mice with cisplatin gives rise to highly affected mitochondria ,nuclei and nucleoli and these noticeable changes may be due to the direct toxic effect of cisplatin on glutathione, lipid perioxidation, bloking of DNA replication and interference with the functions of nucleic acids . 


\section{Hassan M.El Ashmaoui}

(a)

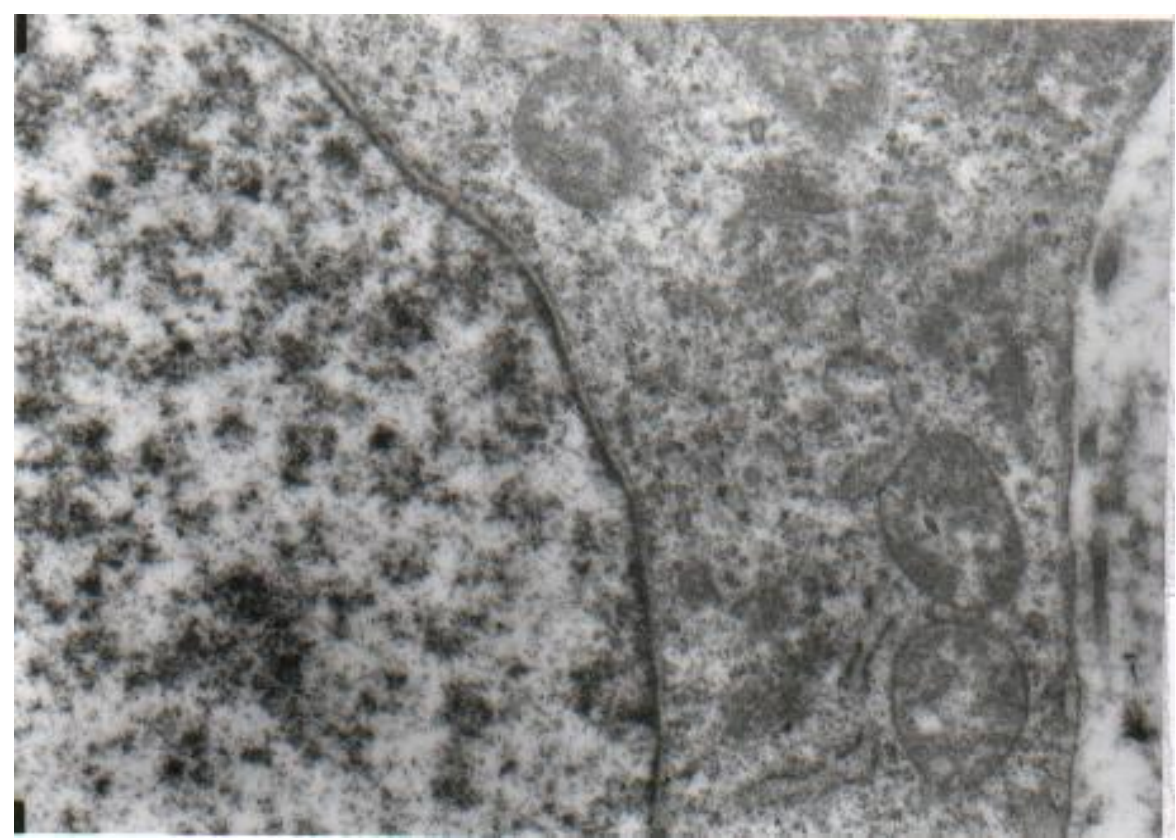

(b)

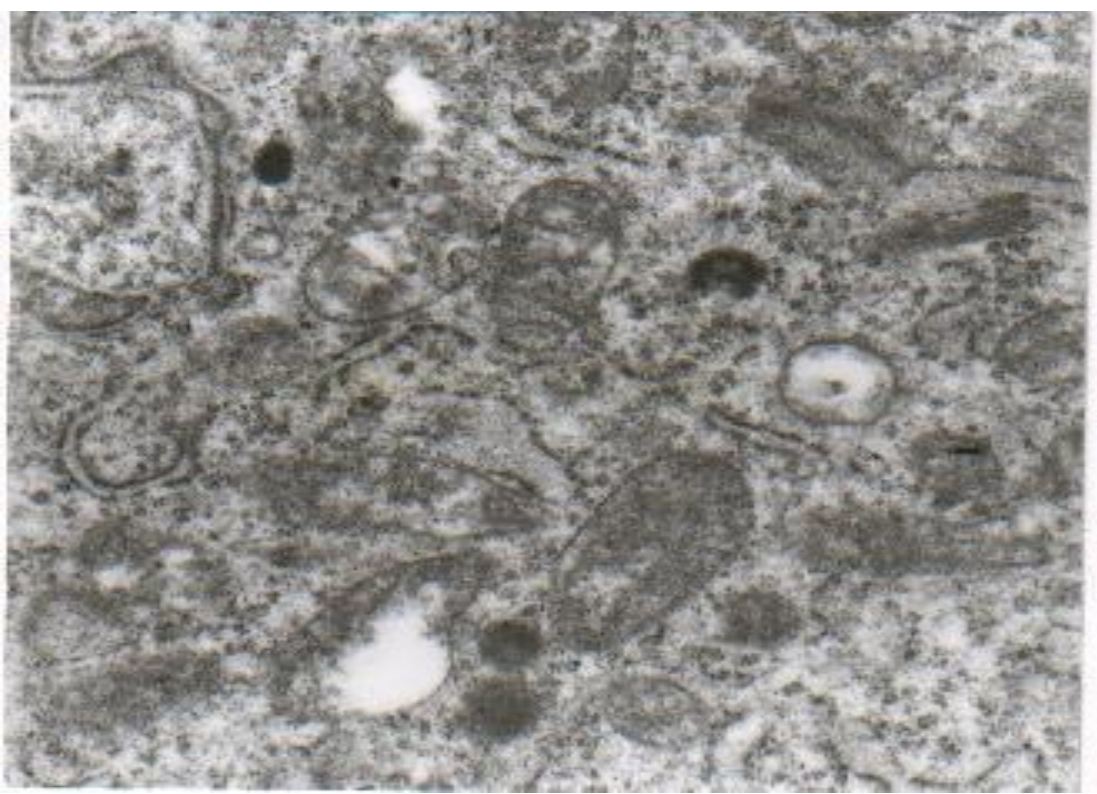

FIG1)

Electron micrograph of mice embryo cell after administration of cisplatin $(7 \mathrm{mg} / \mathrm{kg})$ in day 4 of gestation and killed after $24 \mathrm{~h}$ after administration showed beginning of mitochondriol damage with normal nucleus and few number of lysosomes $(\mathbf{a} \& b)(X 15500)$ 
(a)

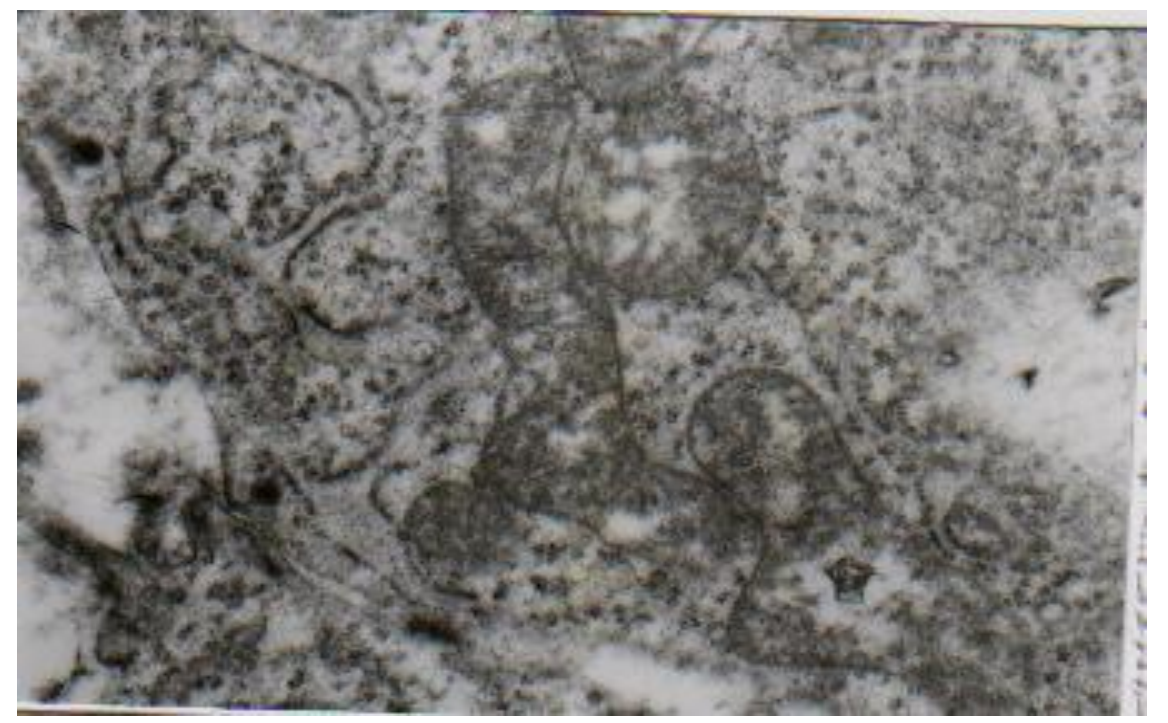

(b)

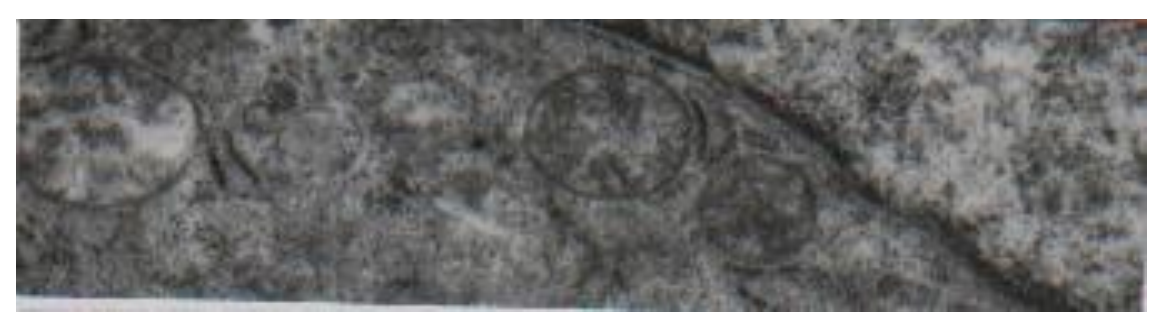

(c)

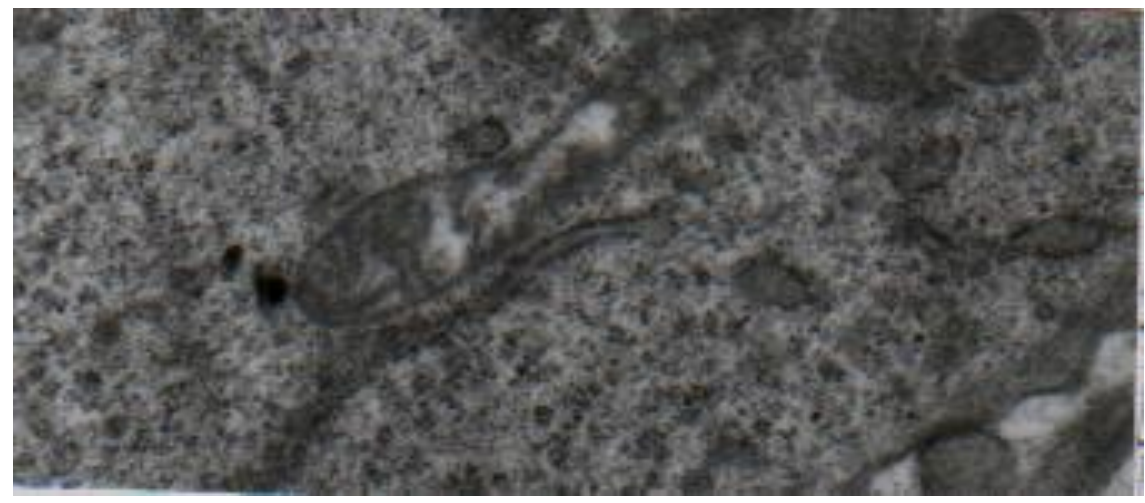

(FIG 2)

Electron micrograph of mice embryo cell after administration of cisplatin $(7 \mathrm{mg} / \mathrm{kg})$ in day 4 of gestation and killed after $48 \mathrm{~h}$ post administration

Showed Mitochondrial deformation, elongation, and disintegration. (X15500) 


\section{Hassan M.El Ashmaoui}

(a)

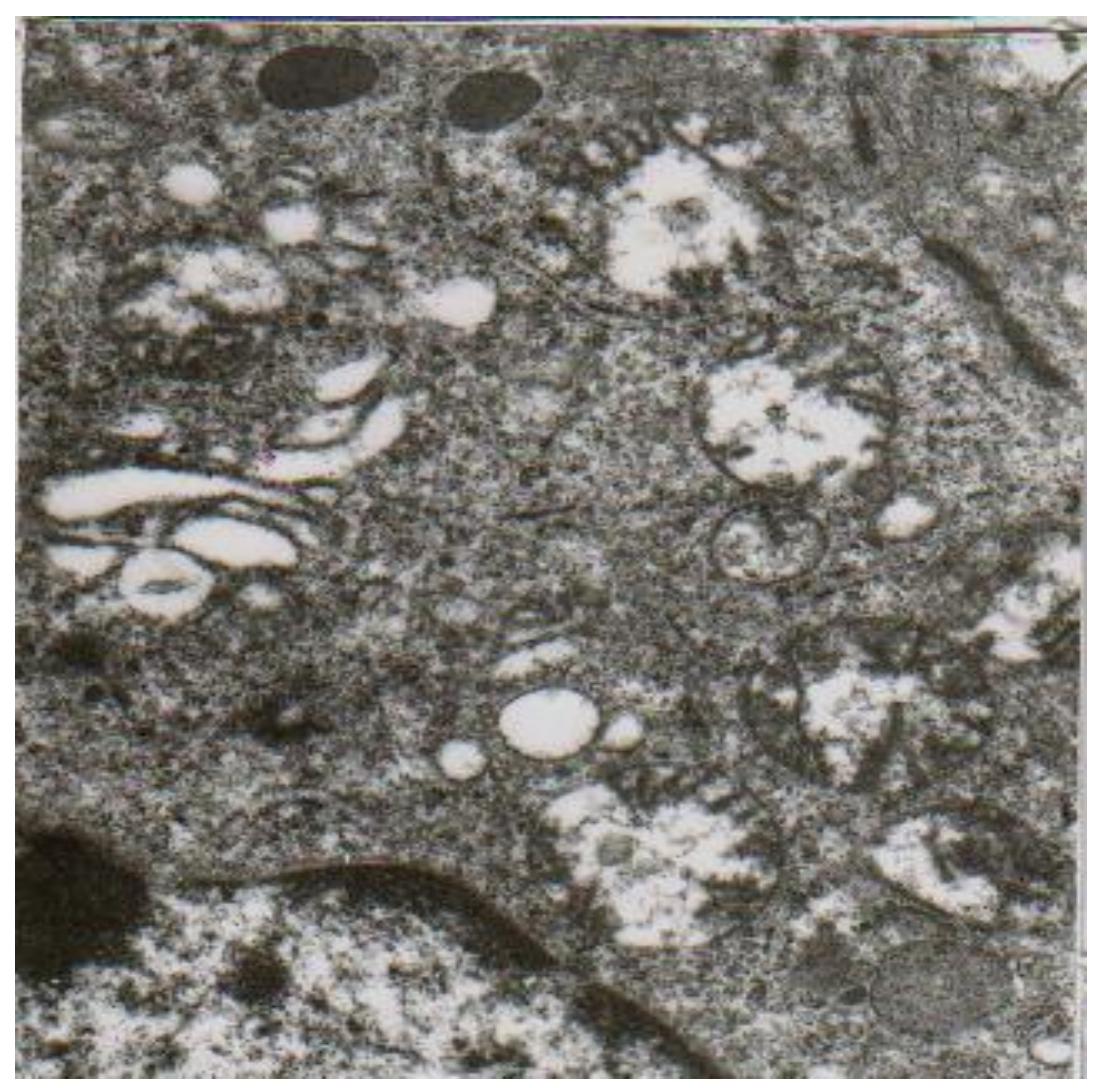

(b)

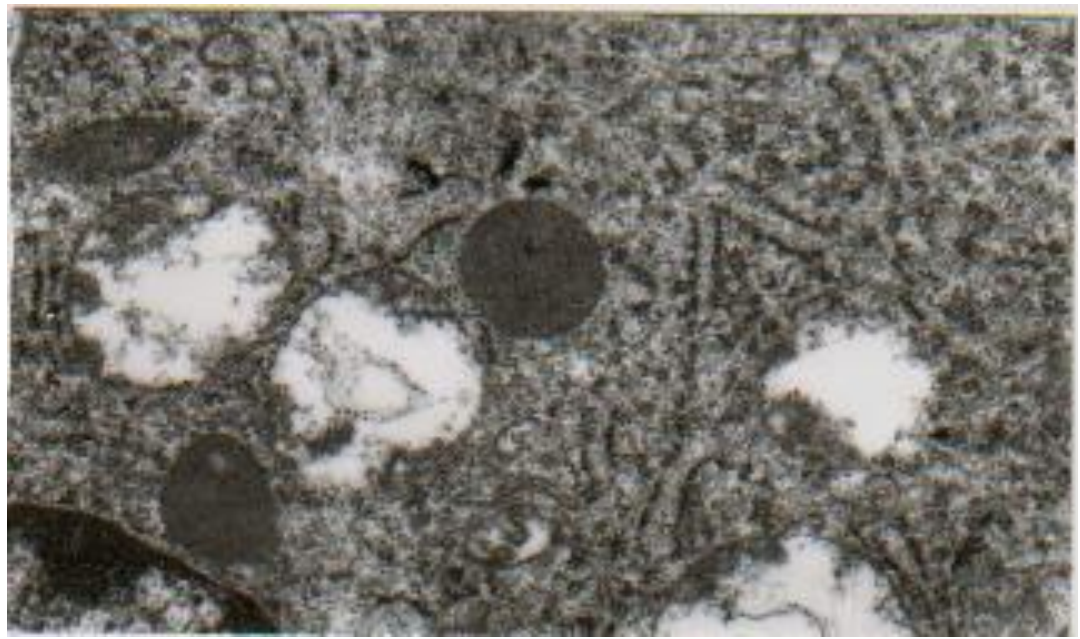

(FIG3) Electron micrograph of mice embryo cell after administration of cisplatin (7mg/ $/ \mathrm{kg})$ in day 4 of gestation and killed after $72 \mathrm{~h}$ after administration

Showed characteristics Mitochondrial lesion and degeneration, vacuoliation, accompanied by disappearance of cristae. (X15000) 


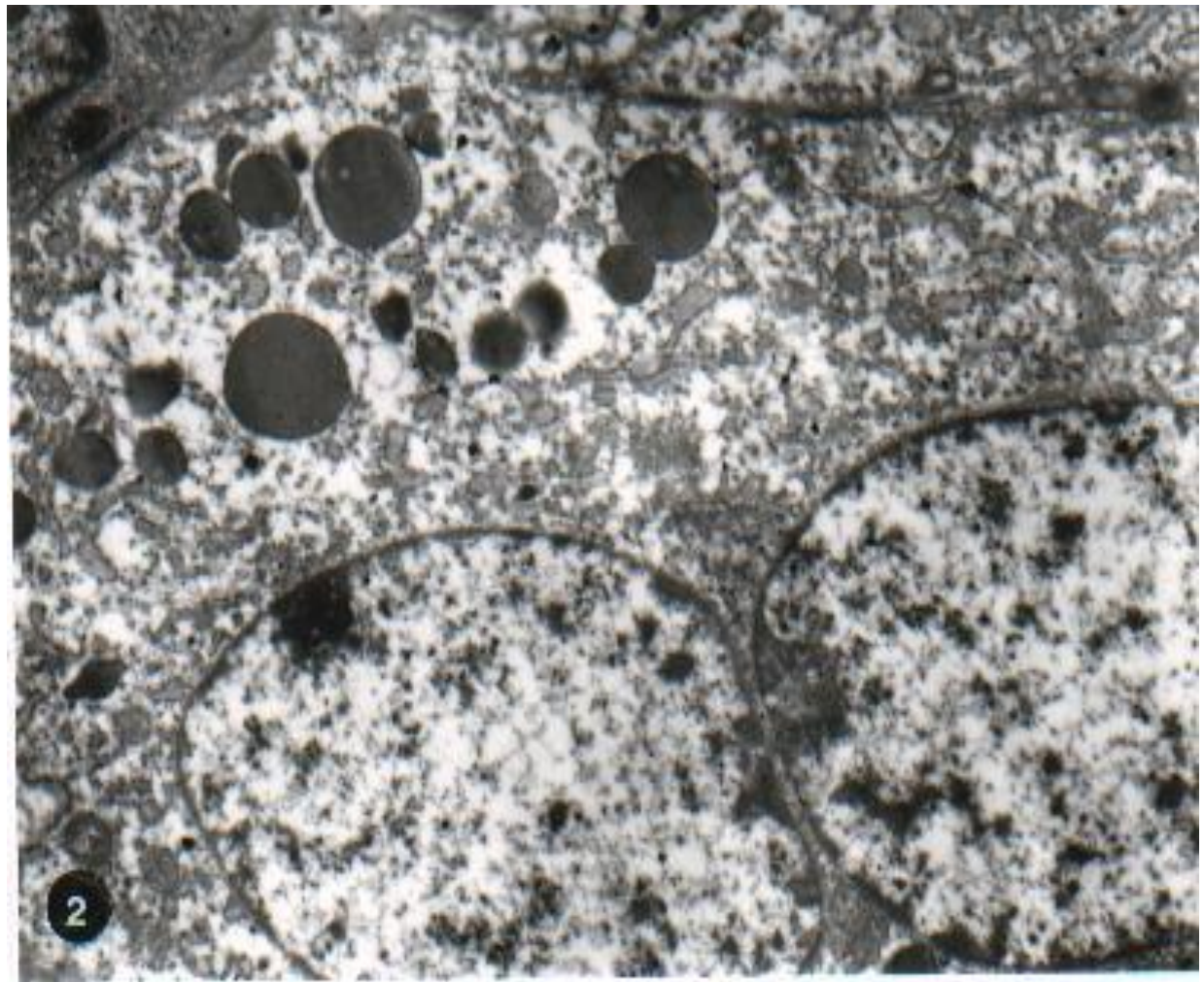

(FIG 4 a) Electron micrograph of mice embryo cell after administration of cisplatin $(7 \mathrm{mg} / \mathrm{kg})$ in day 4 of gestation and killed after $48 \mathrm{~h}$ after administration showed increased perichromatin granules, with dense granular element in the nucleolus. (X5000)

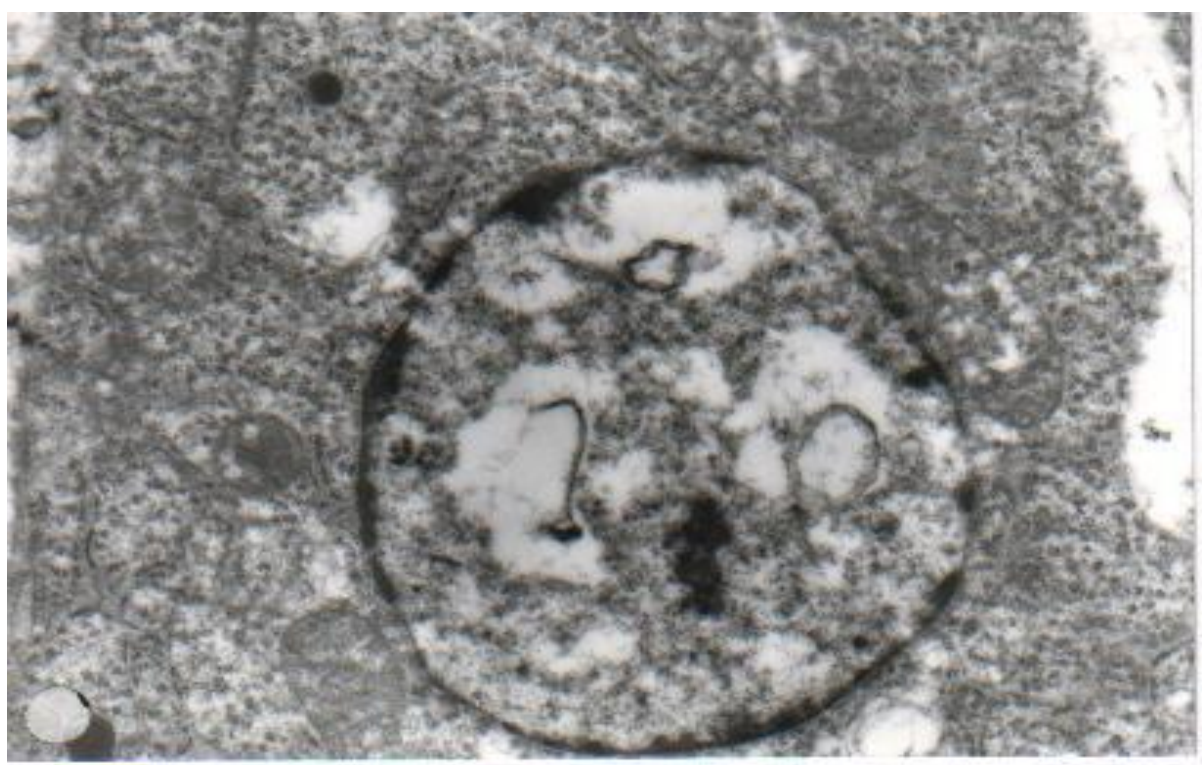

(FIG 4) b Electron micrograph of mice embryo cell after administration of cisplatin $(7 \mathrm{mg} / \mathrm{kg})$ in day 4 of gestation and killed after $72 \mathrm{~h}$ after administration Showed vacuolated nucleus with marginal chromatin and irregular nucleolus (V)(X5000) 


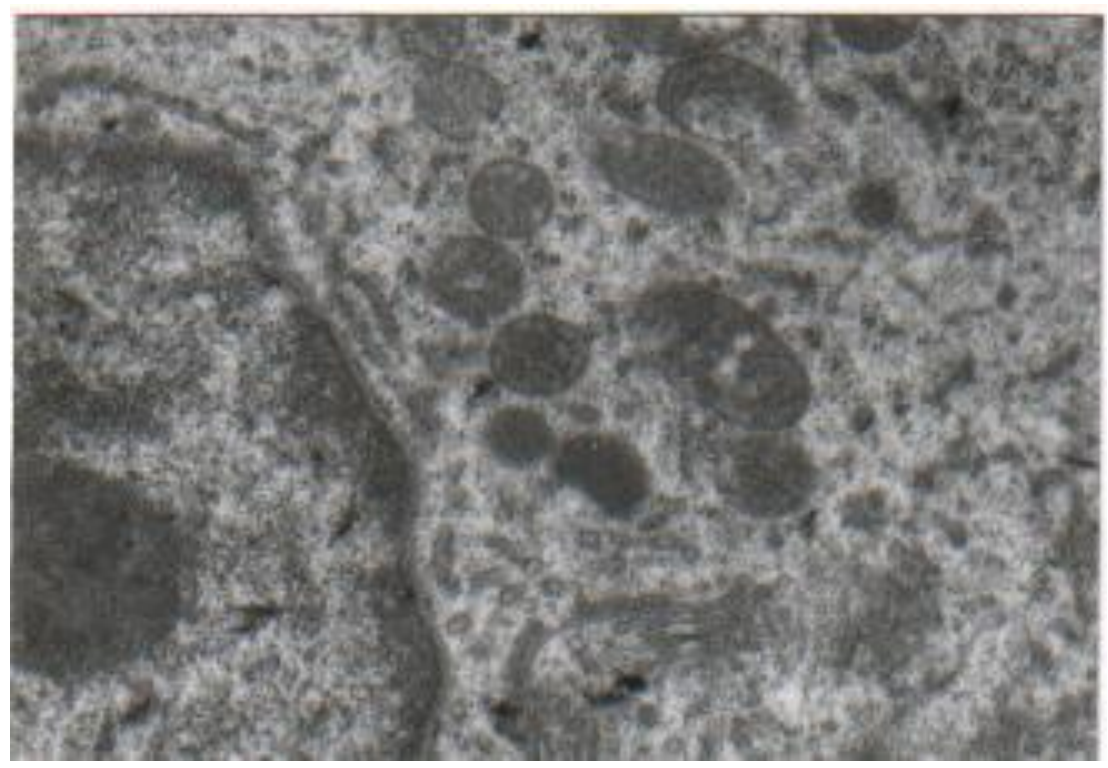

(a)(X15000)

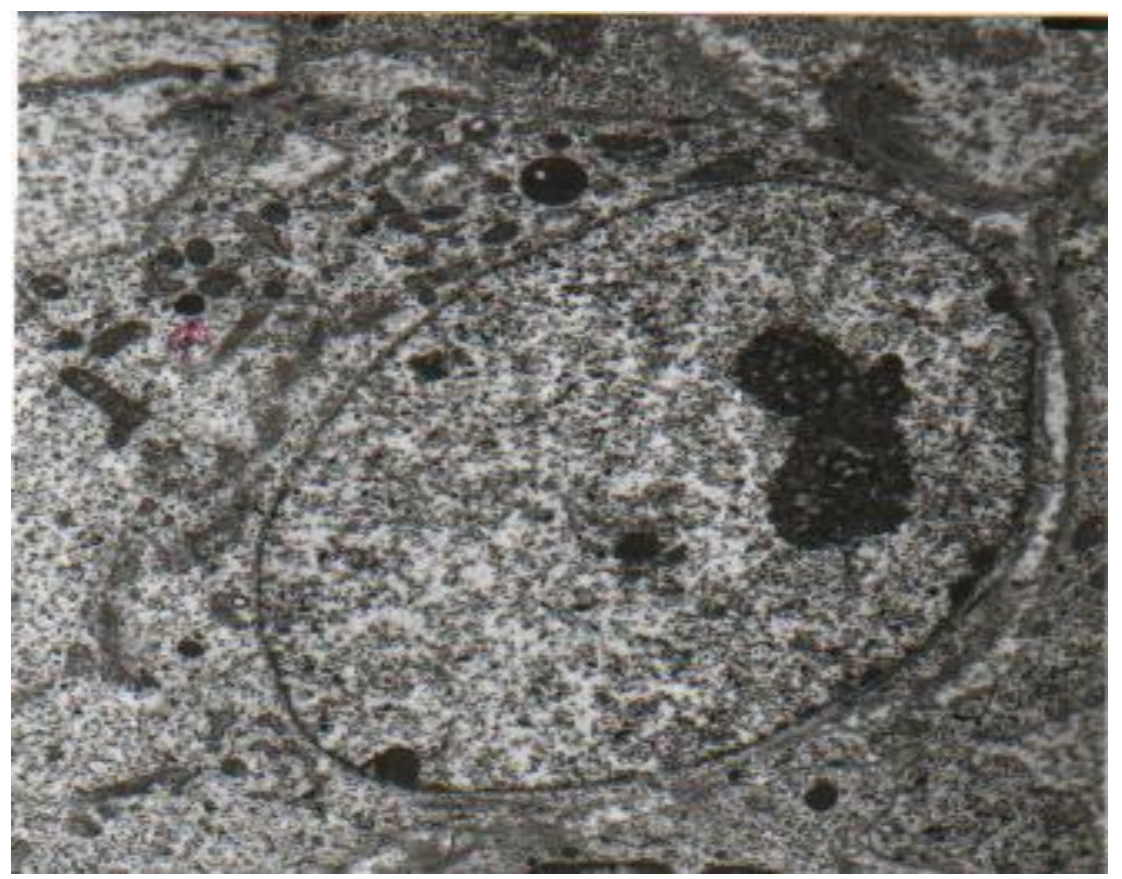

(b)(X5000)

(FIG 5) Electron micrograph of mice embryo cell after administration of normal saline (control group) in day 4 of gestation and killed after $24 \mathrm{~h}$ after administration showed normal structure of mitochondria and nucleus.

With different sizes of lysosomes 


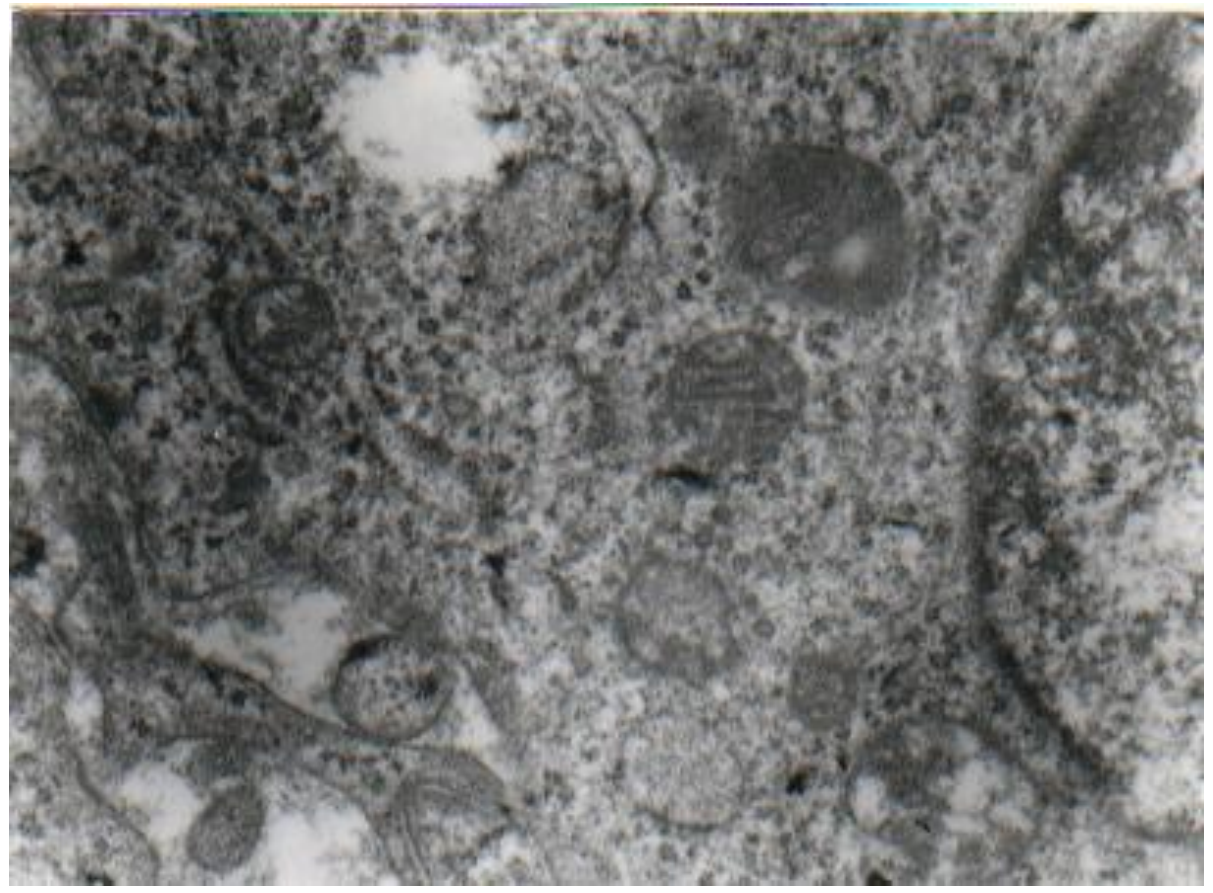

(a) $(\mathbf{X 1 5 0 0 0 )}$

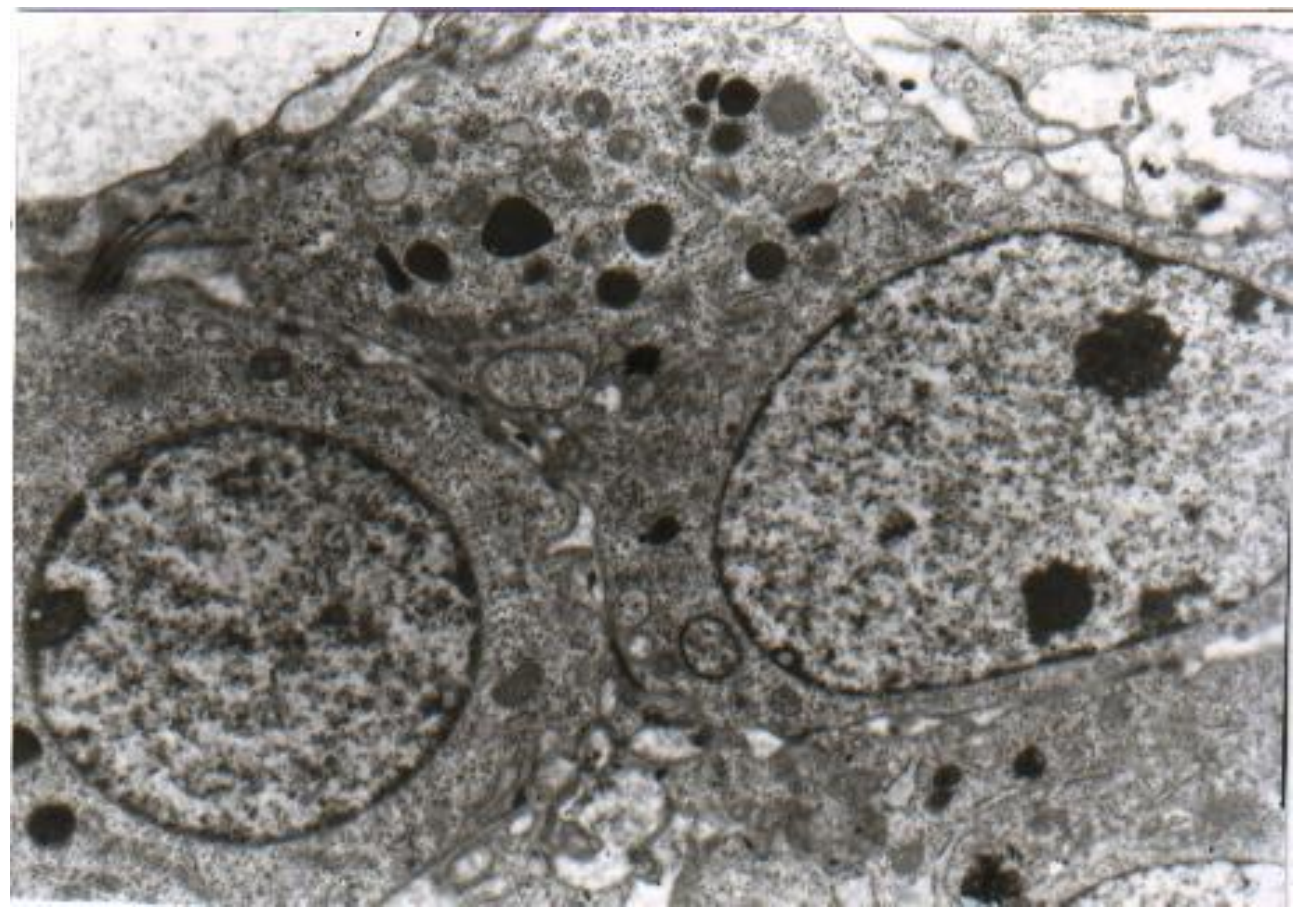

(b)(X5000)

(FIG 6) Electron micrograph of mice embryo cell after administration of normal saline (control group) in day 4 of gestation and killed after $48 \mathrm{~h}$ after administration showed normal structure of mitochondria, lysosomes and nucleus. 


\section{Hassan M.El Ashmaoui}

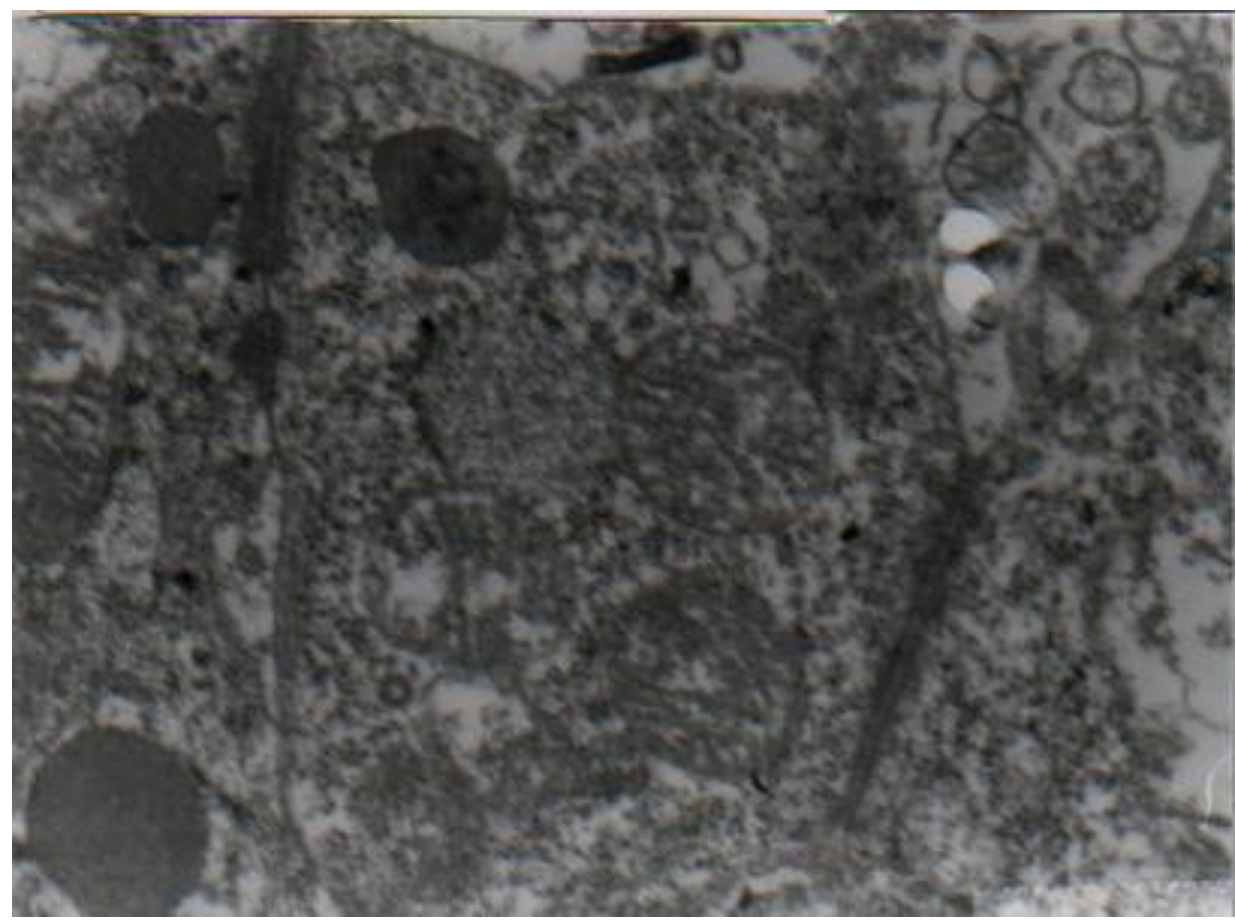

(a)(X20000)

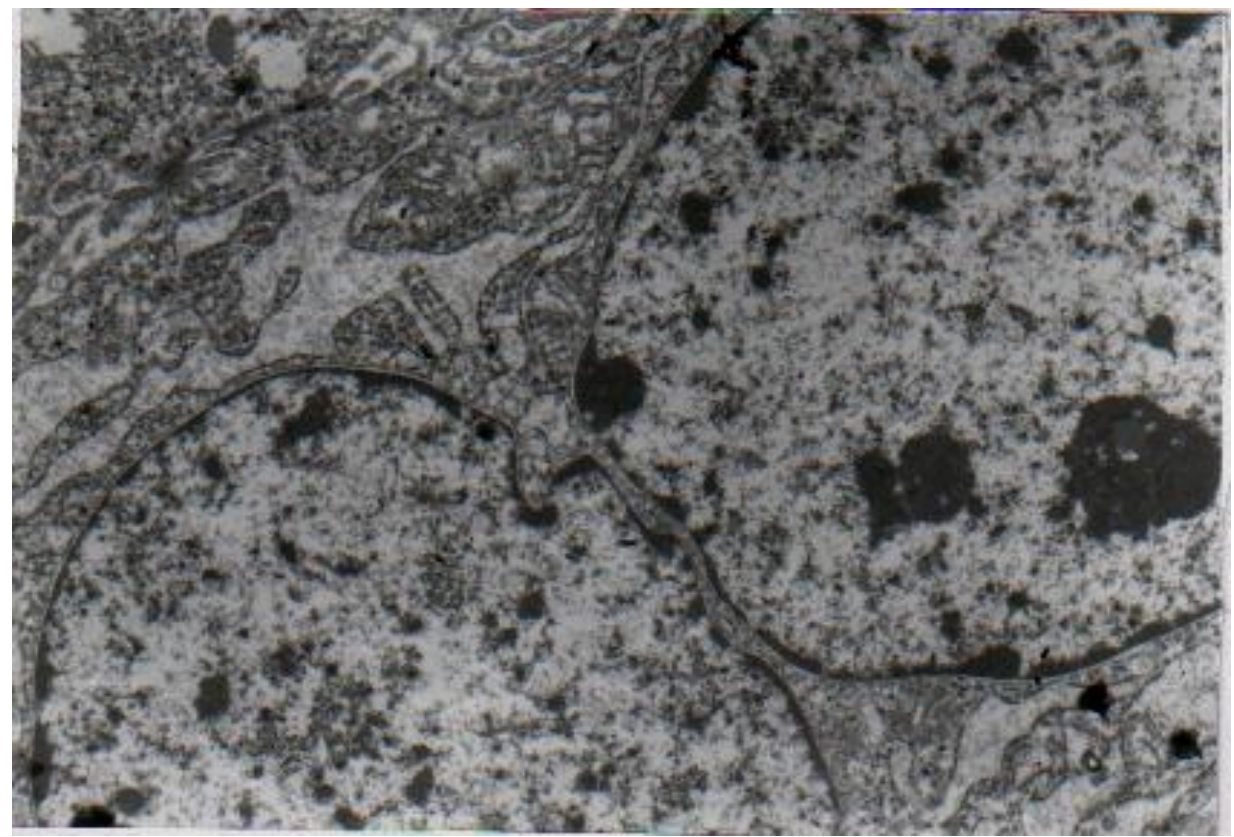

(b) $(\mathbf{X 6 0 0 0 )}$

FIG 7) Electron micrograph of mice embryo cell after administration of normal saline (control group) in day 4 of gestation and killed after $72 \mathrm{~h}$ after administration showed normal structure of mitochondria , nucleus. and lysosomes 


\section{Acknoledgements}

This work was supported by the Reasearch center of college of scienceKingsaud university no (ZOO / 1420 10) , Dr. F. Abou Tarboush and F.A Aty

\section{Reffereces}

1. Aggarwal,. SK; Sodhi, A. (1973): Cytotoxic effects of cis-diclodiammine platinu II on mammalian cells in vitro :A fine ultrasound study. Cytobiologie $7: 366$ - 374

2. Amand,A.J; Bashey,B. (1993): Newer insights into cisplatin nephrotoxicity. Ann Pharmacother 27:1519 -1525.

3. Bellon ,S.F., Colemann, J.H. and Lippard, S.J. (1991): DNA unwinding produced by site specific intrastrand cross - links of antitumor drug cisdiamminedichloroplatinum. Biochemistry 30:80268035.

4. Burhn, S. I., H; Toney, L.C., Lippard (1990) :Biological processing of DNA modified by platinum compounds .Prog. inorg Chem $38: 477-516$

5. Giavini , I.; Lemonica, P. ; Lou, Y.;.Broccia, M.L.; and Prati, M.. (1990): Induction of micronuclei and toxic effects in embryos of pregnant rats treated before impl antation with anticancer drugs :Cyclophosphamide ,Cisplatinum, Adrino- mycin. Teratogenesis ,Carcinogenesis, and Mutagenesis 10:417 - 426

6. Harder, H.C. and Resenberg ,B. (1970): Inhibitory effect of anti tumor platinum compounds on DNA, RNA and protein synthesis in mammalian cells in vitro. Int J. Cancer $6: 207$ - 211.

7. Mollman,J.E.(1990): Cisplatin neurotoxicity. N. Engl.J.Med.322:126 - 127.

8. Pinto, LS., and Lippard, I. (1985): Binding of the anti tumour drug. Cisdiaminedichloroplatinum II (cisplatin) to DNA. Biochim Biophys. Acta 780: 167 180.

9. Rosen, M.; Figliomeni, M. and Simpkins, H. (1992) : The interaction of platinum antitumour drugs with mouse liver mitochondria. Int .J. Exp.Path 73:6174 .

10. Rosenberg, B . (1975) : Possible mechanism for the antitumor activity of platinum coordination complexes . Cancer chemother. Reports 59: 589 - 598 .

11. Rozencweig, M;Von Hoff, D.D; Slavik, M ; Muggia, F. M. (1977): Cis - diamminedicloroplatinum II A new anticancer drug. Animals in Med 86:803 - 812 .

12. Zhang - Jin. G. and Edward, L.W. (1994): Cisplatin nephrotoxicity: Decrease in mitochondrial protein sulphydryl concentration and calcium uptake by mitochondria from rat renal cortical slices. Biochemical pharmacology. 47( 7) :1127 - 1135 
التغير ات الحادثة فى المينوكوندريا والقو اه فى أجنة الفئر ان المعاملة بمضاد السرطان سيسيلاتينوم

\section{حسن مدلوح العشّاوى \\ المركز القومى للبحوث - قسم بيولوجيا الخلية}

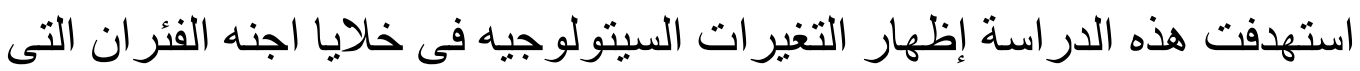

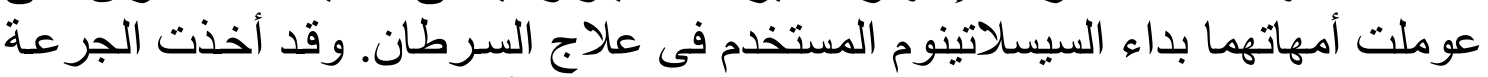

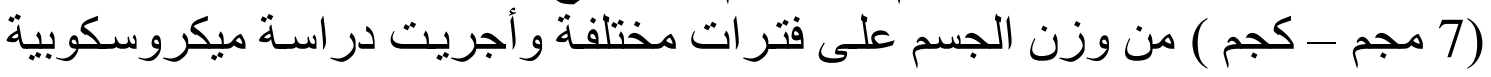

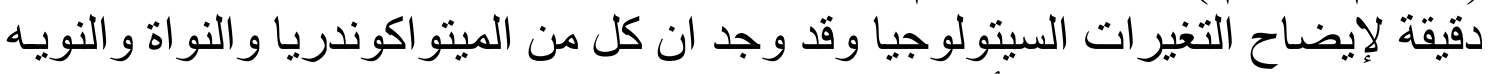

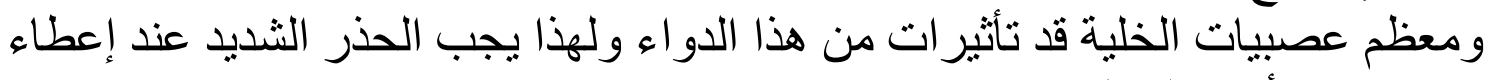
هذه الادويه أنثاء الحمل 